\title{
Vascular endothelial growth factor as a survival factor for human islets: effect of immunosuppressive drugs
}

\author{
S. E. Cross • S. K. Richards • A. Clark • A. V. Benest • \\ D. O. Bates $\cdot$ P. W. Mathieson • P. R. V. Johnson • \\ S. J. Harper $\cdot$ R. M. Smith
}

Received: 20 December 2006 / Accepted: 7 March 2007 /Published online: 3 May 2007

(C) Springer-Verlag 2007

\begin{abstract}
Aims/hypothesis Rapamycin, part of the immunosuppres-
Abstract
Aims/hypothesis Rapamycin, part of the immunosuppressive regimen of the Edmonton protocol, has been shown to inhibit vascular endothelial growth factor (VEGF) production and VEGF-mediated survival signalling in tumour cell lines. This study investigates the survival-promoting activities of VEGF in human islets and the effects of rapamycin on islet viability.
\end{abstract}

S. E. Cross - S. K. Richards - P. W. Mathieson - R. M. Smith Academic Renal Unit, Southmead Hospital, University of Bristol, Bristol, UK

\section{S. E. Cross - P. R. V. Johnson}

Islet Transplant Research Group, Nuffield Department of Surgery, University of Oxford,

Oxford, UK

\section{A. Clark}

Oxford Centre for Diabetes, Endocrinology and Metabolism, University of Oxford,

Oxford, UK

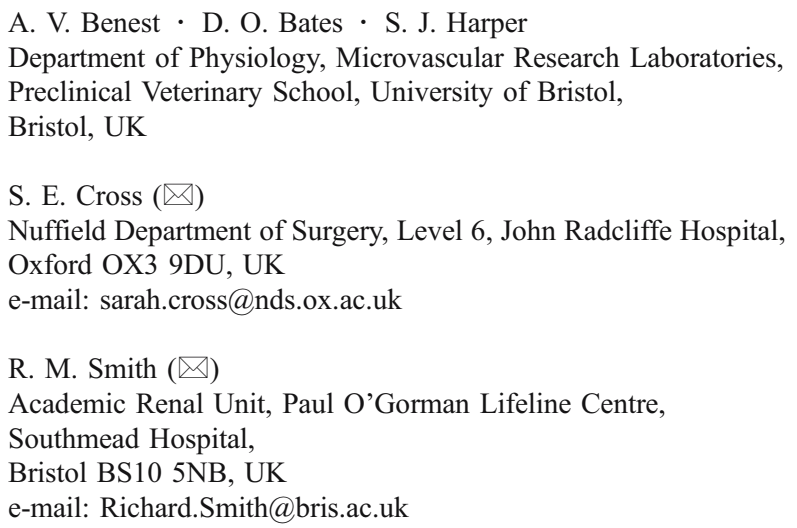

Materials and methods Levels of VEGF and its receptors in isolated human islets and whole pancreas was determined by western blotting and immunostaining. Islet viability following VEGF or immunosuppressive drug treatment was determined using a 3-(4,5-dimethylthiazol-2-yl)-2,5-diphenyltetrazolium bromide (MTT) assay. Islet VEGF release was measured by ELISA. Mouse islets infected with an adenovirus expressing the gene for VEGF were transplanted syngeneically into streptozotocin-induced diabetic mice, with blood glucose levels measured three times per week.

Results Isolated human islets produced multiple isoforms of VEGF and VEGF receptors 1, 2 and 3 and the coreceptor neuropilin 1. Exogenous VEGF $(10 \mathrm{ng} / \mathrm{ml})$ prevented human islet death induced by serum starvation, which suggests that VEGF can act as a survival factor for human islets. Transplantation of mouse islets infected with a $V E G F$-expressing adenovirus in a syngeneic model, improved glycaemic control at day 1 post-transplantation $(p<$ $0.05)$. Rapamycin at 10 and $100 \mathrm{ng} / \mathrm{ml}$ significantly reduced islet VEGF release (by $37 \pm 4 \%$ and $43 \pm 6 \%$, respectively; $p<0.05$ ) and at $100 \mathrm{ng} / \mathrm{ml}$ reduced islet viability (by $36 \pm 9 \%$ ) and insulin release (by $47 \pm 7 \%$, all vs vehicle-treated controls; $p<0.05)$. Tacrolimus had no effect on islet VEGF release or viability.

Conclusions/interpretation Our data suggest that rapamycin may have deleterious effects on islet survival posttransplantation, both through a direct effect on islet viability and indirectly through blockade of VEGF-mediated revascularisation.

Keywords Diabetes mellitus · Islet - Islet transplantation · Rapamycin · Vascular endothelial growth factor · VEGF 


$\begin{array}{ll}\text { Abbreviations } & \\ \text { EC } & \text { endothelial cell } \\ \text { EtBr } & \text { ethidium bromide } \\ \text { FDA } & \text { fluorescein diacetate } \\ \text { MOI } & \text { multiplicity of infection } \\ \text { MTT } & \text { 3-(4,5-dimethylthiazol-2-yl)-2,5-diphenyl- } \\ & \text { tetrazolium bromide } \\ \text { RhVEGF }_{165} & \text { recombinant human VEGF } \\ \text { TBST } & \text { Tris-buffered saline with } 0.05 \% \text { Tween } 20 \\ \text { VEGF } & \text { vascular endothelial growth factor } \\ \text { VEGF-R } & \text { VEGF receptor }\end{array}$

\section{Introduction}

Successful pancreatic islet transplantation achieves significantly better glycaemic control than is achieved with bolus insulin injections, with almost complete resolution of hypoglycaemia even with partial graft function [1-4]. Increased availability of this procedure is therefore an important goal.

A key feature of the Edmonton protocol [1] is an increased functional islet mass relative to previous protocols. This is achieved by transplantation of only high-yield islet preparations (to reach a minimum of 10,000 islet equivalents $/ \mathrm{kg}$ ) and by performing multiple transplants. Equally important is maximisation of islet viability at all stages of the isolation and transplant procedure, including use of a less diabetogenic, corticosteroid-free, immunosuppressive regimen (daclizumab, tacrolimus and rapamycin). Even with optimised protocols, islets are subject to multiple insults post-transplantation that result in significant islet loss [5-7]. Thus, therapeutic manoeuvres capable of promoting revascularisation and preventing early cell death will permit the survival of an adequate islet mass to achieve sustainable insulin independence and thus optimise the use of donated cadaveric human pancreases. Such treatments need to prevent the loss of transplanted islets and beta cells, which may contribute to significant graft failure beyond 1 year from transplant. The aim of this study was to determine the role of vascular endothelial growth factor (VEGF) as an autocrine survival factor for beta cells and to investigate the effects of the immunosuppressant rapamycin. We propose that this pathway may be important in preservation of transplanted beta cell mass.

In addition to its potent angiogenic action, the conventional VEGF isoform, VEGF $_{165}$, is a long-established survival factor for endothelial cells (ECs) [8, 9]. More recently, VEGF $_{165}$ has been demonstrated to promote survival in an autocrine manner for a number of other cell types, including podocytes [10], renal tubular epithelial cells [11], haematopoietic stem cells [12] and tumour cells [13].
VEGF-A (generally referred to simply as VEGF) is the founder member of a family of growth factors that includes VEGF-A, -B, -C, -D, -E and placental growth factor. Multiple isoforms of human VEGF-A are generated from splicing of $V E G F$ pre-mRNA, resulting in two families of isoforms. Conventional pro-angiogenic $\left(\mathrm{VEGF}_{\mathrm{xxx}}\right)$ and the recently described anti-angiogenic $\left(V_{E G F} F_{x x} b\right)$ families result from differential splicing of exon 8 ( $x x x$ representing amino acid number). Differential splicing in exons 6 and 7 produces isoforms within each family with varying heparin binding activity (e.g. 189, $189 b, 165,165 b$, etc) [14-17]. Since revascularisation and beta cell survival have been implicated in the short- and medium-term survival of islets, this study considers the role of the predominant pro-angiogenic, pro-epithelial survival isoform, $\mathrm{VEGF}_{165}$.

In the rat, hypoxia induces increased production of VEGF $_{120}$ and VEGF $_{164}$ isoforms (equivalent to human VEGF $_{121}$ and VEGF $_{165}$ ) and VEGF receptor 1 (VEGF-R1, also known as Flt-1) and 2 (VEGF-R2, also known as KDR/Flk-1) in islets [18-21]. Following transplantation, rat islets produce VEGF specifically in insulin-producing cells [22]. Transfection of murine islets with $V E G F_{165}$ cDNA [23], or encapsulation of rat islets in collagen supplemented with recombinant human $\mathrm{VEGF}_{165}$ $\left(\right.$ rhVEGF $\left._{165}\right)$ [24] has been shown to increase revascularisation and improve graft function. Thus, VEGF may be expected to ameliorate damage to islets in the immediate post-transplant period. Array technology has shown that isolated human islets express VEGF [25], and it has been reported that VEGF protein is co-expressed with insulin [26], as in the rat. The production of VEGF receptors by human islets has not been characterised in detail. It is well known that the effect of immunosuppressive agents on beta cell insulin secretion varies between species, with beta cell lines being more sensitive to their adverse effects than rodent islets, and human islets being the most resistant [27, 28]. These important inter-species differences in the basic physiology of beta cells may also be apparent when investigating the physiology of VEGF in islets.

In this study we examined the effects of $\mathrm{VEGF}_{165}$ on islet survival in vitro by characterising endogenous VEGF isoform production, the VEGF receptor profile and the effects of rhVEGF 165 on serum starvation-induced islet and beta cell death. We used a murine islet transplant model to assess the effect of $\mathrm{VEGF}_{165}$ overexpression on in vivo islet graft function. Tacrolimus and rapamycin are central to the Edmonton protocol. Rapamycin has been reported to promote apoptosis of tumour cell lines, in part by inhibition of VEGF release [29]. We therefore investigated the effect of tacrolimus and rapamycin on human islet survival and VEGF release. 


\section{Materials and methods}

All chemicals/solutions were obtained from Sigma (Poole, UK) unless otherwise stated.

Isolation and culture of human pancreatic islets Human islets were isolated from pancreases obtained from cadaveric multi-organ donors, with consent of next of kin and with ethics committee approval. Islets were purified by collagenase digestion and continuous density gradient centrifugation on a COBE 2991 cell separator (Gambro BCT, Lakewood, CO, USA), as described in the Edmonton protocol [1]. Islet number and purity were assessed using dithizone staining. All experiments were performed on islets from a single donor in duplicate and repeated at least twice on islets from successive donors.

Human islets were cultured in CMRL 1066 (Biochrom, Berlin, Germany), supplemented with $10 \%$ FCS, 2 mmol/1 L-glutamine, 100 units $/ \mathrm{ml}$ penicillin and $100 \mu \mathrm{g} / \mathrm{ml}$ streptomycin at $37^{\circ} \mathrm{C}$ under conditions of $95 \%$ air and $5 \% \mathrm{CO}_{2}$ in untreated Petri dishes. The culture media was changed every 3-4 days, and experiments were carried out within 10 days of islet isolation.

MIN6 cell culture MIN6 insulinoma cells (passages 39-44) were cultured in $\mathrm{T} 175 \mathrm{~cm}$ flasks in $25 \mathrm{mmol} / 1$ glucose DMEM, supplemented with $15 \% \mathrm{FCS}, 4 \mathrm{mmol} / \mathrm{l} \mathrm{L}$-glutamine, 100 units $/ \mathrm{ml}$ penicillin and $100 \mu \mathrm{g} / \mathrm{ml}$ streptomycin at $37^{\circ} \mathrm{C}$ under conditions of $95 \%$ air and $5 \% \mathrm{CO}_{2}$.

VEGF and immunosuppressive drug treatment Tacrolimus (Prograf; Fujisawa, Staines, UK) was solubilised in ethanol (Fisher Scientific, Loughborough, UK) at a concentration of $1 \mathrm{mg} / \mathrm{ml}$ and rapamycin was solubilised in DMSO at a concentration of $0.5 \mathrm{mg} / \mathrm{ml}$. Both were stored at $-20^{\circ} \mathrm{C}$, and dilutions to working concentrations in CMRL were made fresh from stock before each experiment. The experimental concentrations chosen spanned the range of plasma drug levels achieved clinically $(0.1,1,10$ and $100 \mathrm{ng} / \mathrm{ml}$ ). The final concentration of ethanol or DMSO in the culture medium was less than $0.1 \%$. $\operatorname{rhVGF}_{165}$ (R\&D Systems, Abingdon, UK) was used at concentrations of 1 , 10 or $100 \mathrm{ng} / \mathrm{ml}$ in medium without FCS.

Human islets $(1,000$, purity of $90 \%)$ per well of a 24 -well untreated culture plate were incubated in $1 \mathrm{ml}$ rhVEGF $_{165}$ or drug at working concentrations or vehicle control, in CMRL (without FCS for VEGF experiments) for $72 \mathrm{~h}$ at $37^{\circ} \mathrm{C}$. Groups of mouse islets were cultured in serum-free RPMI, supplemented with $11 \mathrm{mmol} / \mathrm{l}$ glucose, 100 units $/ \mathrm{ml}$ penicillin and $100 \mu \mathrm{g} / \mathrm{ml}$ streptomycin, in $35 \mathrm{~mm}$ untreated Petri dishes, with rhVEGF $_{165}$ or vehicle control for $72 \mathrm{~h}$ at $37^{\circ} \mathrm{C}$. MIN6 cells were plated into 12 -well plates in
$25 \mathrm{mmol} / \mathrm{l}$ glucose DMEM for 1-2 days. Medium was removed and cells were incubated in DMEM containing 3\% FCS and rhVEGF $_{165}$ for $72 \mathrm{~h}$ at $37^{\circ} \mathrm{C}$. Following drug treatment, conditioned medium was collected and stored at $-80^{\circ} \mathrm{C}$ until measurement of total VEGF release by ELISA. The viability of rhVEGF $_{165}$ or drug-treated cells or human islets was assessed using a 3-(4,5-dimethylthiazol-2-yl)2,5-diphenyltetrazolium bromide (MTT) assay. For assessment of islet function following drug treatment, islets were subjected to a static insulin release assay.

Determination of cell viability and the release of insulin and VEGF Viability of human islet and MIN6 cells was assessed using an MTT assay. Following VEGF or immunosuppressive drug treatment, islets were pelleted, the supernatant fraction was collected for measurement of total VEGF release, and the islets were then resuspended in $1 \mathrm{ml}$ of MTT solution ( $1 \mathrm{mg} / \mathrm{ml}$ in PBS) and incubated for $4 \mathrm{~h}$ at $37^{\circ} \mathrm{C}$. Following VEGF treatment of MIN6 cells, medium was removed, replaced with MTT solution and incubated as above. Thereafter, well contents were removed, spun, and the supernatant fraction was discarded. Each pellet was dissolved in $50 \mu \mathrm{l}$ 2-propanol, and the optical density of the resultant coloured solution was measured at a wavelength of $490 \mathrm{~nm}$ on a plate reader. Mouse islet viability was assessed using fluorescein diacetate (FDA), which stains live cells green, and ethidium bromide $(\mathrm{EtBr})$, a red dye which can permeate only cells with damaged membranes. A solution of FDA and $\mathrm{EtBr}$ (both at $0.1 \mathrm{mg} / \mathrm{ml}$ ) was added to islets for 3 min before two rinses with Hanks' balanced salt solution and then examination under a fluorescent microscope. The percentage of dead cells in the islet was then approximated by visual enumeration.

Insulin release was determined using a glucose-stimulated insulin secretion assay. Following drug treatment, 20 islets from each experimental group were hand-picked into wells of a 96-well round-bottomed culture plate (Iwaki, Tokyo, Japan) and washed once with $3.2 \mathrm{mmol} / 1$ glucose RPMI. This was done in duplicate. Islets were then exposed to $3.2 \mathrm{mmol} / 1$ glucose RPMI (basal glucose concentration) for $30 \mathrm{~min}$ at $37^{\circ} \mathrm{C}$. Medium was subsequently removed and replaced with either 3.2 or $25 \mathrm{mmol} / \mathrm{l}$ glucose RPMI, and the islets incubated at $37^{\circ} \mathrm{C}$ for $2 \mathrm{~h}$. Insulin released into the medium was measured by ELISA (DRG, Marburg, Germany).

The amount of VEGF released by islets into the culture medium under different conditions was determined using a sandwich ELISA kit (Human VEGF DuoSet, R\&D Systems), according to the manufacturer's instructions.

Determination of islet VEGF and VEGF receptor production by western blot analysis Protein was extracted from islets by homogenisation in ice-cold radioimmunoprecipi- 
tation assay (RIPA) buffer $(150 \mathrm{mmol} / \mathrm{l} \mathrm{NaCl}, 1 \%$ Nonidet P-40, 5\% deoxycholic acid, 1\% SDS, $50 \mathrm{mmol} / 1$ Tris $(\mathrm{pH}$ 8.0), $10 \mu \mathrm{l} / \mathrm{ml}$ protease inhibitor cocktail) and then quantified using a protein assay (Bio-Rad, Hemel Hempstead, UK). Lysates of cultured human glomerular ECs (derived from glomeruli isolated from normal human kidney; Applied Cell Biology Research Institute, Kirkland, WA, USA) and sieved human glomeruli (as previously described [30]), kind gifts from S. C. Satchell (Academic Renal Unit, University of Bristol, Bristol, UK), were used as controls.

Protein samples were diluted 4:1 with $4 \times$ SDS sample buffer (100 mmol/1 Tris, $\mathrm{pH} 6.8,6 \%$ glycerol, 3\% SDS, 5\% $\beta$-mercaptoethanol, $0.1 \%$ bromophenol blue) and heated at $95^{\circ} \mathrm{C}$ for $5 \mathrm{~min}$. Equal amounts of protein were loaded into $10 \%$ polyacrylamide gels, run at $200 \mathrm{~V}$ for $45 \mathrm{~min}$, and then transferred onto nitrocellulose at $200 \mathrm{~V}$ for $1 \mathrm{~h}$. The membranes were blocked with $5 \%$ non-fat dried milk in Tris-buffered saline with $0.05 \%$ Tween $20(38 \mathrm{mmol} / 1$ Tris$\mathrm{HCl}, 150 \mathrm{mmol} / 1 \mathrm{NaCl}, 0.05 \%$ Tween 20 in distilled water; TBST), followed by overnight incubation at $4{ }^{\circ} \mathrm{C}$ with the following primary antibodies: anti-VEGF (VEGF-C1) at a 1:100 dilution; anti-amylase, anti-VE-cadherin and antineuropilin $1(\mathrm{~Np} 1-\mathrm{H} 286)$ at a 1:200 dilution; anti-VEGF-R1 (Flt1-C17) at a 1:300 dilution; anti-VEGF-R3 (Flt4-C20) at a 1:400 dilution (all from Santa Cruz Biotechnology, Santa Cruz, CA, USA); and anti-VEGF-R2 (Upstate, Milton Keynes, UK) at a 1:2,000 dilution. Anti- $\beta$-actin was used at a 1:5,000 dilution as a loading control. All antibody dilutions were made in 5\% non-fat dried milk TBST.

After primary antibody incubation, blots were washed with TBST and then incubated for $1 \mathrm{~h}$ with the appropriate horseradish peroxidase-conjugated secondary antibody. After washing, the blots were developed using the enhanced chemiluminescence system (Amersham Life Sciences, Little Chalfont, Bucks, UK) or the SuperSignal West Femto Maximum Sensitivity Substrate Kit (Pierce, Rockford, IL, USA). For examination with a second antibody, membranes were stripped by incubating at $60^{\circ} \mathrm{C}$ for $30 \mathrm{~min}$ in stripping buffer $(100 \mathrm{mmol} / \mathrm{l} \beta$-mercaptoethanol, 2\% SDS, $62.5 \mathrm{mmol} / \mathrm{l}$ Tris- $\mathrm{HCl}, \mathrm{pH}$ 6.7) and subsequently blocked and reprobed with a second primary antibody.

Localisation of VEGF receptors in human islets by immunohistochemical and fluorescence staining Tissue was taken from the body region of three human pancreases before islet isolation. Tissue was fixed in $10 \%$ formalin in $0.9 \%$ buffered saline and prepared for paraffin wax embedding. Serial sections $(4 \mu \mathrm{m})$ were cut onto coated slides. Sections were subjected to heat-induced epitope retrieval with slides immersed in $10 \mathrm{mmol} / \mathrm{l}$ sodium citrate, and then endogenous peroxidase activity was blocked with hydrogen peroxide treatment. Slides were incubated with $5 \%$ normal swine serum for $20 \mathrm{~min}$, followed by primary antibodies (as above; VEGF-R1, VEGF-R2 or neuropilin 1 at dilutions of 1:50, 1:500 and 1:50, respectively), together with insulin (guinea pig anti-insulin antibody) at a 1:200 dilution, overnight at $4{ }^{\circ} \mathrm{C}$. A secondary goat anti-rabbit antibody conjugated to horseradish peroxidase (Dako, Ely, UK) was used, and VEGF receptor antibody binding was localised with diamino benzidine hydrochloride. Insulin labelling on the same section was localised with a goat anti-guinea pig antibody (Santa Cruz Biotechnology) conjugated to rhodamine. Slides were examined under a fluorescence microscope.

Mouse islet isolation, ex vivo gene transfer and transplantation of VEGF ${ }_{165}$ over-expressing islets Inbred male C57BL/6 mice, aged 8-14 weeks (20-25 g) were used as donors and transplant recipients. Mice were housed in a specific pathogen-free facility at the University of Bristol, at $22^{\circ} \mathrm{C}$ with a $12 \mathrm{~h} \mathrm{light/dark} \mathrm{cycle} \mathrm{and} \mathrm{free} \mathrm{access} \mathrm{to}$ chow and water. Procedures were performed in accordance with the UK Home Office regulations.

Mouse islets were isolated and transplanted as previously described [31]. Briefly, islets were isolated by digesting pancreases with collagenase $\mathrm{P}$ and purified on a discontinuous Ficoll density gradient as described by Gotoh et al. [32]. Islets were hand-picked and transferred to DMEM supplemented with $10 \% \mathrm{FCS}, 11 \mathrm{mmol} / 1$ glucose, $100 \mathrm{units} / \mathrm{ml}$ penicillin and $100 \mu \mathrm{g} / \mathrm{ml}$ streptomycin for culture.

Adenoviruses expressing $V E G F_{165}\left(\mathrm{Ad}-\mathrm{VEGF}_{165}\right)$ were generated as described [33]. Mouse islets were infected with Ad-VEGF 165 or a null virus, at a multiplicity of infection (MOI) of five plaque-forming units per cell, for $1 \mathrm{~h}$. Islets were hand-picked and transplanted immediately.

To induce diabetes in transplant recipients, animals were fasted overnight and then given $160 \mathrm{mg} / \mathrm{kg}$ of streptozotocin by intraperitoneal injection, 3 days before transplantation. Mice were anaesthetised, and then 200 islets infected with either null virus $(n=10$ mice) or Ad-VEGF 165 ( $n=9$ mice) were implanted under the left renal capsule. Blood glucose analysis, using an Accuchek II blood glucose monitor (Roche Diagnostics, Basel, Switzerland), was performed on samples taken from the tail vein on postoperative day 1 and three times per week up to postoperative day 20 .

Statistical analysis All data are expressed as means \pm SEM. Control and experimental conditions were compared using unpaired $t$ tests. A $p$ value of $\leq 0.05$ was considered significant. For graphic and statistical analysis the software package Prism (Graphpad Software, San Diego, CA, USA) was used. 


\section{Results}

Human islets produce VEGF and VEGF receptors Protein production of multiple VEGF isoforms was detected by western blotting of protein extracted from islets on days 0 5 post-isolation. The multiple bands found are consistent with the different VEGF isoform dimers of amino acid length 121, 145, 165 and 189 residues (Fig. 1a).

Production of VEGF-R1, -R2, -R3 and neuropilin 1 protein was detected by immunoblotting of protein extracted from islets $0-5$ days post-isolation (Fig. $1 \mathrm{~b}$ ). There was no change in the levels of VEGF-R1, -R2, -R3 or neuropilin 1 over time in culture; therefore, only blots from day 1 and day 5 are shown. Full-length VEGF-R2 was seen in isolated islets at each day post-isolation, together with bands of lower weights (70 and $97 \mathrm{kDa}$ ), which represent known degradation products of the receptor. The $70 \mathrm{kDa}$ product is present at early time points, but its expression diminishes over time. The opposite is true for the $97 \mathrm{kDa}$ product, which is observed from day 2 onwards. The bands of a lower molecular weight than that predicted for VEGFR3 are the correct size for the VEGF-R3 monomer.

Since residual ECs within the islet may be the source of VEGF receptors, a comparison was made by immunoblotting for the endothelial-specific molecule VE-cadherin. VEcadherin was detected in the EC-positive control lysate, but not in the islet samples. Exocrine contamination of the islet preparations was assessed by probing the islet lysates for amylase. Amylase was detected only in islets on day 1 postisolation and not at days $2-5$, suggesting that it is the endocrine cells themselves that produce the VEGF receptors. However, we could not exclude the possibility that ductal cells present in the islet extract also produce VEGF receptors, as VEGF-R2 expression has previously been demonstrated in pancreatic ducts [34]. Therefore, to confirm which cell types in the islet express the VEGF receptors, immunostaining of pancreas sections was performed (Fig. 1c). VEGF-R1, -R2 and neuropilin 1 expression was detected in islet cells, and the receptors were found to be colocalised with insulin, thereby suggesting that beta cells express them. Only occasional labelling was detected for VEGF-R2 in pancreatic ductal cells, which were insulin-negative (data not shown).

rhVEGF ${ }_{165}$ rescues human and mouse islets and MIN6 beta cells from serum starvation-induced cell death and improves mouse islet graft function The finding that human islets produce VEGF and its receptors suggested the existence of an autocrine feedback loop. To determine whether VEGF could act as a survival factor, serum-starved human islets were treated for $72 \mathrm{~h}$ with exogenous $\mathrm{rhVEGF}_{165}$ and then subjected to an MTT viability assay. Treatment with rhVEGF $_{165}$ rescued human islets from a

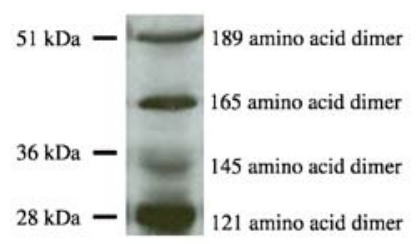

b
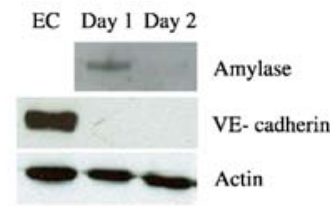

Gloms Day 1 Day 5

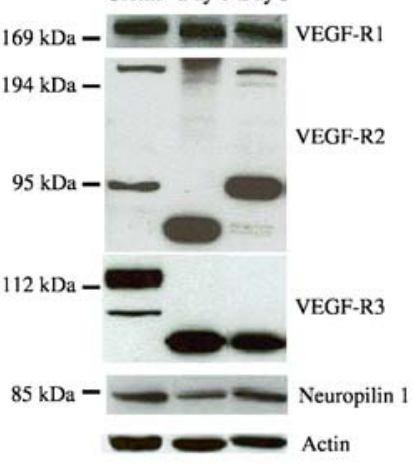

C
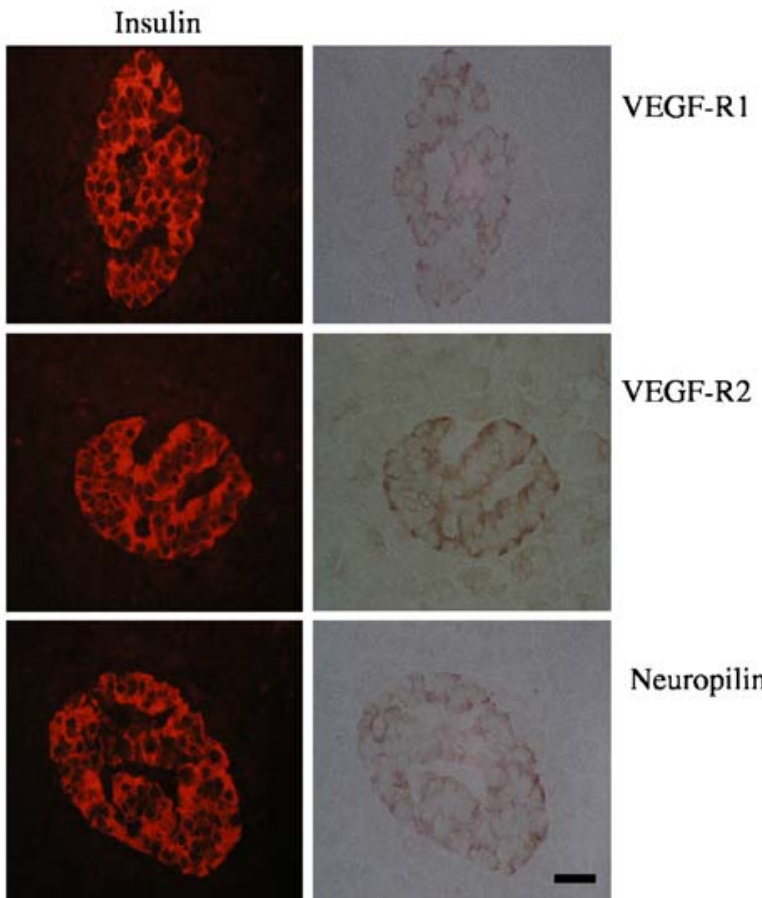

Neuropilin

Fig. 1 Expression of VEGF and its receptors in isolated human islets and human pancreas. a Human islets were lysed, proteins resolved by SDS-PAGE, and then immunoblotted with anti-pan-VEGF antibody as described in the "Materials and methods" section. Molecular weight markers are indicated on the left, VEGF isoform sizes are indicated on the right. b Full-sized VEGF-R1, -R2, -R3 and neuropilin 1 production examined by western blotting showed $\sim 180, \sim 230, \sim 85$ and $\sim 80 \mathrm{kDa}$ bands, respectively. Blots for amylase and VE-cadherin were used to check for exocrine and endothelial cell contamination, respectively. Whole human glomeruli (Gloms) or glomerular endothelial cell (EC) lysates are shown as positive controls. Blots representative of three separate islet preparations are presented. c Immunohistochemical and fluorescence staining of human pancreas for VEGF-R1, VEGF-R2 and neuropilin 1 with insulin. VEGF receptors are colocalised with insulin in the beta cells. Images shown are representative of three different human pancreases. All images are at $\times 400$ magnification; bar $=30 \mu \mathrm{m}$ 
serum starvation-induced cell death in a dose-dependent manner. At a concentration of $10 \mathrm{ng} / \mathrm{ml}, \mathrm{rhVEGF}_{165}$ elicited a significant increase in cell viability of approximately $37 \%$ as compared with the untreated control $(p<0.05$; Fig. 2a). VEGF treatment was able to rescue MIN6 beta cells from serum starvation-induced death, albeit with a bell-shaped dose-response curve (Fig. 2b). The maximal protective effect was seen with $10 \mathrm{ng} / \mathrm{ml} \mathrm{rhVEGF}_{165}(225 \pm 14 \%$ of control; $p<0.05$ ). As shown by $\mathrm{FDA} / \mathrm{EtBr}$ viability staining, treatment with $10 \mathrm{ng} / \mathrm{ml}$ rhVEGF $_{165}$ for $72 \mathrm{~h}$ improved serum-starved mouse islet viability (Fig. 2c). The percentage of cells stained with $\mathrm{EtBr}$ (red), and therefore dead, was estimated per islet, with an average of ten islets assessed per treatment group, in two independent experiments. Approximately $70 \%$ of cells in control islets were stained red, compared with only $20 \%$ of cells in $\mathrm{rhVEGF}_{165}$-treated islets.

We explored the effect of VEGF on mouse islet graft outcome in vivo by monitoring the survival and function of a suboptimal islet mass transplanted into syngeneic diabetic mice. Mice transplanted with Ad-VEGF-infected islets $(n=9)$ showed a significant improvement in glycaemic control over the 20-day period as compared with mice transplanted with islets infected with a null, control virus $(n=10)$, in which euglycaemia was not achieved $(p<0.0001)$ (Fig. 2d). Interestingly, a significant difference in blood glucose levels between mice transplanted with Ad-VEGFinfected islets and mice transplanted with null, control virus-infected islets was observed as early as day 1 posttransplantation $(p<0.05)$.

Effect of immunosuppressive drugs on human islet viability, VEGF release and glucose-stimulated insulin secretion A dose-dependent reduction in islet viability was found after $72 \mathrm{~h}$ of rapamycin treatment (Fig. 3a). With $100 \mathrm{ng} / \mathrm{ml}$ rapamycin treatment there was a $36 \pm 9 \%$ reduction in MTT metabolism compared with control islets $\left(\mathrm{OD}_{490 \mathrm{~nm}} 0.159 \pm\right.$ 0.014 for $100 \mathrm{ng} / \mathrm{ml}$ rapamycin-treated islets vs $0.251 \pm 0.030$ for control islets; $p<0.01$ ). Rapamycin was found to have a dose-dependent inhibitory action on the release of total VEGF, with the threshold concentration for reduction of VEGF production being $10 \mathrm{ng} / \mathrm{ml}$ (VEGF release $0.304 \pm$ $0.011 \mathrm{pg}$ islet $^{-1} 72 \mathrm{~h}^{-1}, 62 \pm 4 \%$ of control; $p<0.05$ ). Treatment with $100 \mathrm{ng} / \mathrm{ml}$ rapamycin reduced islet VEGF release to $56 \pm 6 \%$ of that of control islets $(0.273 \pm 0.017 \mathrm{pg}$ islet $^{-1} 72 \mathrm{~h}^{-1}$ vs $0.487 \pm 0.049 \mathrm{pg}_{\text {islet }}{ }^{-1} 72 \mathrm{~h}^{-1}$ for control islets; $p<0.01$ ). Tacrolimus for $72 \mathrm{~h}$ had no effect on either islet viability or VEGF release at any of the concentrations tested (Fig. 3b). The finding that $10 \mathrm{ng} / \mathrm{ml}$ rapamycin reduced islet VEGF release but not viability suggests that rapamycin has a specific mechanism of action, distinct from that of tacrolimus, for inhibition of islet VEGF production. At therapeutic concentrations, both tacrolimus and rapamycin treatment reduced glucose-stimulated insulin secretion

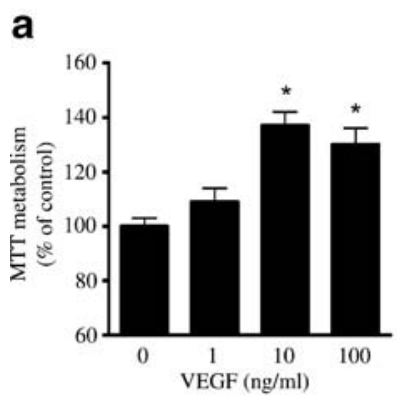

b

C
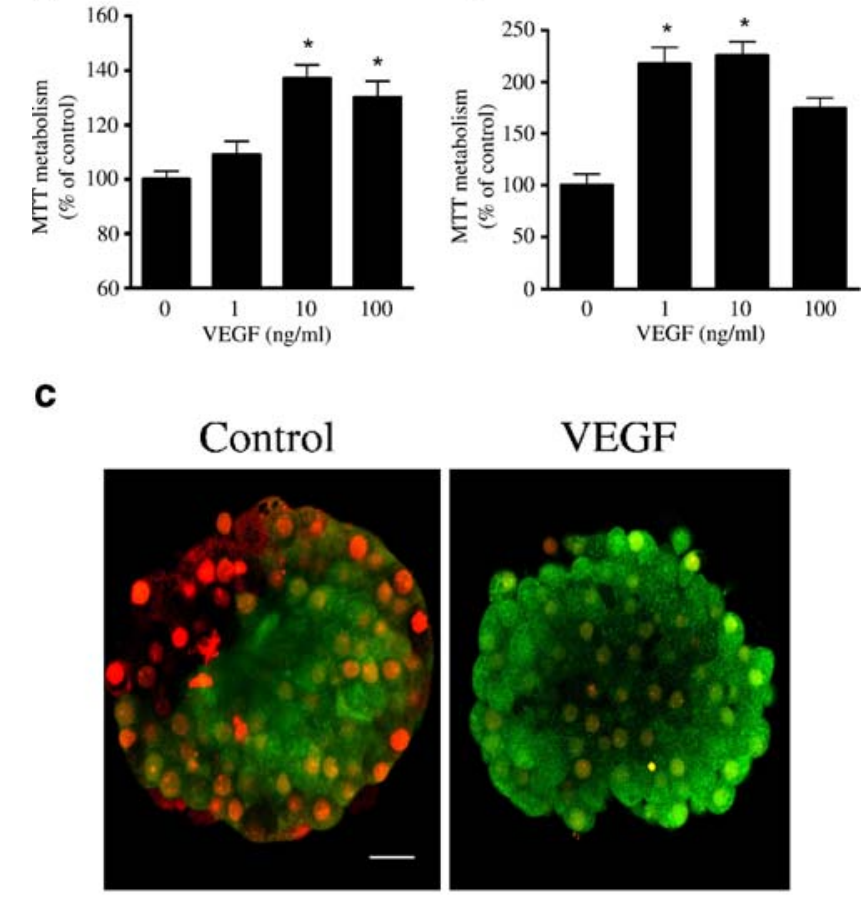

d

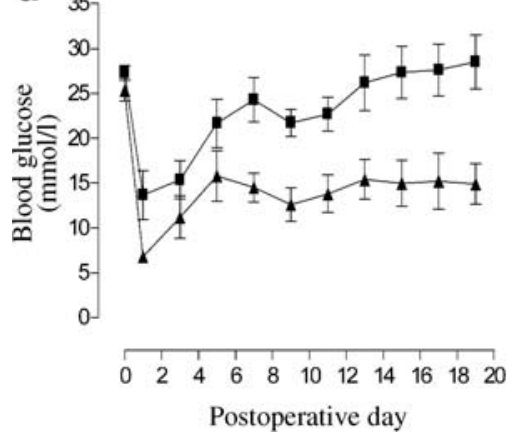

Fig. 2 Effect of VEGF on human islet (a) and MIN6 (b) beta cell viability after treatment for $72 \mathrm{~h}$. Serum-starved islets or MIN6 cells were treated with VEGF for $72 \mathrm{~h}$. An MTT assay was performed to assess islet viability. Graphs show the mean absorbance (as a percentage of control untreated mean) $\pm \mathrm{SEM} ; n=5$ (islets), $n=4$ (MIN6 cells). ${ }^{*} p<0.05$ vs untreated control. c FDA (green) and EtBr (red) staining of serum-starved mouse islets treated with vehicle (control, left panel) or $10 \mathrm{ng} / \mathrm{ml} \mathrm{rhVEGF}_{165}$ (right panel). The percentage of red cells in $\mathrm{rhVEF}_{165}$-treated islets is lower than that in control islets, implying superior viability. Representative examples from two separate experiments are shown. Images are at $\times 630$ magnification; bar $=20 \mu \mathrm{m}$. d Increased VEGF expression in a suboptimal murine islet transplant model is beneficial to glycaemic control. STZ diabetic C56BL/6 mice were transplanted with 200 islets infected with null virus $(n=10)$ or $\operatorname{Ad-VEGF}_{165}(n=9)$ at an MOI of 5. Blood glucose analysis was performed pre-operatively, on postoperative day 1 and alternate days thereafter. The mean blood glucose values in the two groups of animals over the whole 20-day period were $22.89 \pm 0.92$ and $13.52 \pm 0.73 \mathrm{mmol} / 1$ for the animals receiving null virus- and Ad-VEGF 165 -transduced islets, respectively $(p<0.0001)$. Squares, null virus; triangles, Ad-VEGF $_{165}$ 
a

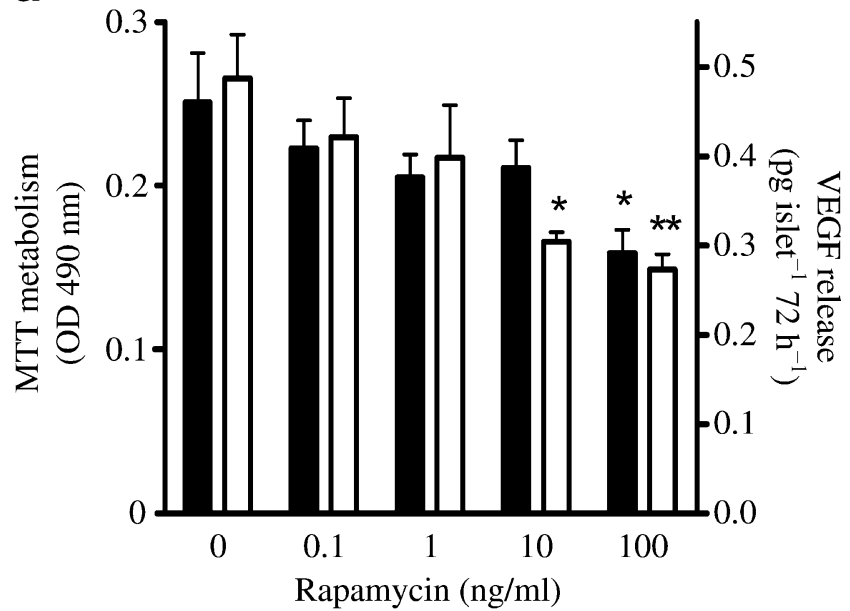

b

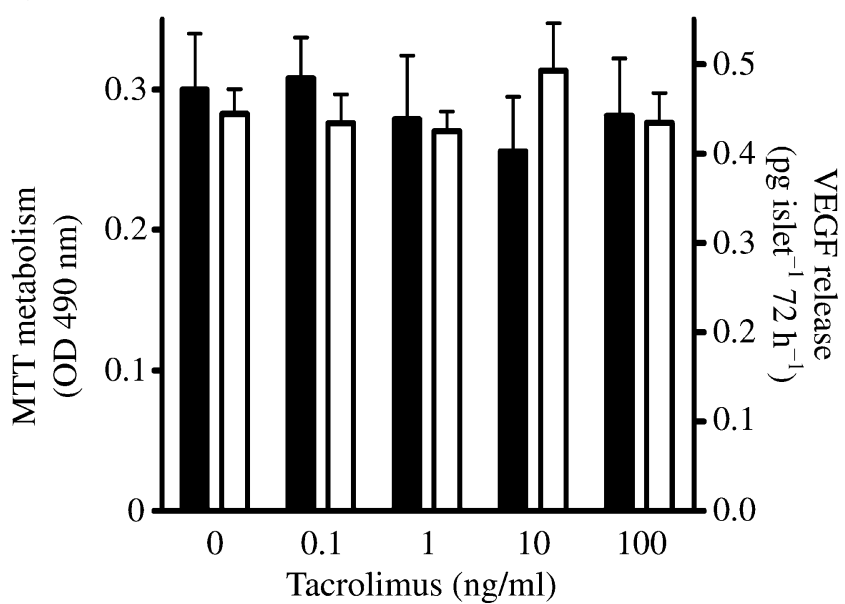

Fig. 3 Effect of immunosuppressive agents on human islet viability and VEGF release after treatment for $72 \mathrm{~h}$. Human islets were cultured with rapamycin (a) or tacrolimus (b) at a range of concentrations or vehicle control $(0.02 \%$ DMSO or $0.01 \%$ ethanol) for $72 \mathrm{~h}$. Cell viability was measured by MTT assay (closed bars). VEGF release into culture medium was measured by ELISA (open bars). The data are the means $\pm \mathrm{SEM}$, of duplicate samples from experiments using islets from four different donors. ${ }^{*} p<0.05,{ }^{* *} p<0.01$ vs corresponding control

(Fig. 4). Tacrolimus reduced insulin release in response to $25 \mathrm{mmol} / \mathrm{l}$ glucose to $52 \pm 8 \%$ and $53 \pm 1 \%$ of control at concentrations of 10 and $100 \mathrm{ng} / \mathrm{ml}$, respectively, $(p<0.05)$. Rapamycin treatment also approximately halved the amount of insulin released in response to $25 \mathrm{mmol} / \mathrm{l}$ glucose, compared with that released from control, vehicle-treated islets $\left(8.0 \pm 0.7\right.$ [pmol/1] islet $^{-1} \mathrm{~h}^{-1} 10 \mathrm{ng} / \mathrm{ml}$ rapamycin, $7.9 \pm 1.0[\mathrm{pmol} / \mathrm{l}]$ islet $^{-1} \mathrm{~h}^{-1} 100 \mathrm{ng} / \mathrm{ml}$ rapamycin vs $14.9 \pm$ $1.3[\mathrm{pmol} / \mathrm{l}]$ islet $^{-1} \mathrm{~h}^{-1}$ control; $\left.p<0.05\right)$.

\section{Discussion}

To date, the study of VEGF in islet transplantation has focused only on its pro-angiogenic activities. However,
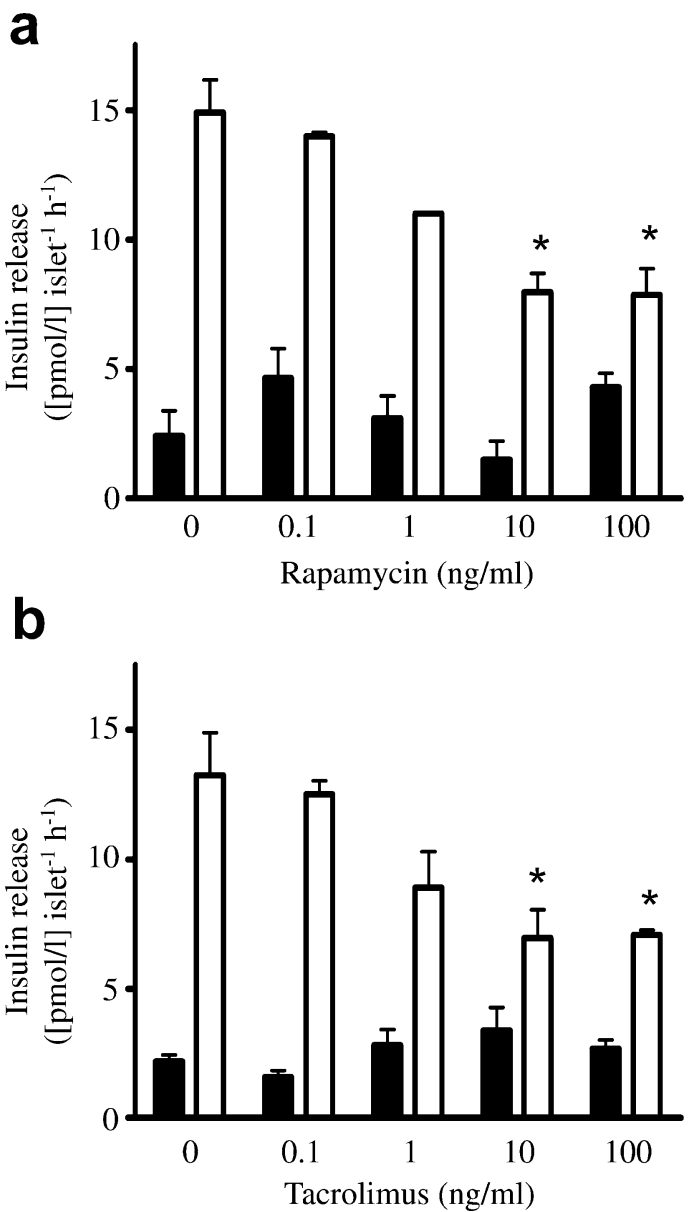

Fig. 4 Insulin secretion from human islets during $2 \mathrm{~h}$ of static incubation under basal $(3.2 \mathrm{mmol} / 1$, closed bars $)$ and stimulatory ( $25 \mathrm{mmol} / \mathrm{l}$, open bars) glucose concentrations. Insulin secretion by drug-treated islets is expressed as pmol/l per islet per $\mathrm{h}$. Data are the means \pm SEM of duplicate samples from experiments using islets from three different donors. Islets were treated with each drug at the concentrations shown for $72 \mathrm{~h}$ previously. A significant reduction in glucose-stimulated insulin secretion was observed after exposure to rapamycin at 10 and $100 \mathrm{ng} / \mathrm{ml}$ (a) and tacrolimus at 10 and $100 \mathrm{ng} / \mathrm{ml}$ (b). $* p<0.05$

VEGF is also an established survival factor for a number of non-endothelial cell types. This, together with the recognition that at least $50 \%$ of infused islets are lost within the first few days following transplantation, led us to explore the possibility that rhVEGF $_{165}$ may act as a survival factor for human islets. We have shown that normal isolated human islets express the VEGF receptors VEGF-R1, -R2 and -R3, as well as the coreceptor neuropilin 1 . We have reproduced the recently described data on VEGF production in isolated human islets [35], yet our data suggest that VEGF is produced under standard culture conditions, in contrast to the hypoxic environment used in the study by Lai et al. [35]. The expression of neuropilin 1 has previously been described in islet cells using immunohistochemistry of pancreas sections from chronic pancreatitis specimens [36]. We have confirmed this observation in normal human pancreas 
sections and have also shown colocalisation of VEGF-R1, -R2 and neuropilin 1 with insulin in the beta cells.

The expression of both full-length and proteolytically processed VEGF receptors suggests the existence of an autocrine survival pathway, as has been previously demonstrated for a number of cell types other than ECs [10-13]. Although the evidence for an autocrine survival pathway in no way reduces the likely importance of the VEGF-induced revascularisation of transplanted islets, capillary sprouting does not start until day 3 or 4 post-isolation [37], by which time more than one-half of the infused islets have been destroyed. $\mathrm{VEGF}_{165}$ may therefore have a double protective action by increasing islet survival early after transplantation and then promoting the revascularisation of those surviving islets. Studies of the effects of pretreatment of islets with VEGF have produced conflicting results [38, 39], but we have demonstrated a beneficial effect of VEGF co-expression on transplanted islet survival in vivo. Glycaemic control was improved as early as day 1 post-transplantation, before the initiation of revascularisation, suggesting that VEGF may have a direct protective effect on islet viability that is independent of revascularisation. A recent study in which human islets were co-infected with adenoviruses encoding rhVEGF $_{165}$ and IL-1 receptor antagonist described an improvement of in vitro islet viability and glycaemic control [40], thereby supporting our hypothesis that $\mathrm{VEGF}_{165}$ may have the potential to act as an islet survival factor.

Rapamycin appears to have deleterious effects on rodent islet viability and function at supra-therapeutic concentrations [41, 42]. One study demonstrated that rapamycin, again at a supra-therapeutic concentration of $50 \mathrm{ng} / \mathrm{ml}$, exerted a negative effect on insulin release from human islets [43]; however, it did not further explore the effects of rapamycin on islet viability. Here we show that rapamycin has detrimental effects on both human islet function and survival, possibly by inhibition of VEGF secretion. The effect on VEGF secretion occurred at a lower concentration $(10 \mathrm{ng} / \mathrm{ml})$ than the effect on viability $(100 \mathrm{ng} / \mathrm{ml})$, so inhibition of VEGF release is unlikely to be a consequence of reduced viability. If VEGF is acting as a survival factor for isolated human islets, then an inhibitory effect of rapamycin on VEGF release and a potential blockade of VEGF-mediated survival signalling pathways may reduce islet viability, in addition to rapamycin-induced inhibition of other mammalian target of rapamycin (mTOR)-mediated cell survival pathways [44]. Interestingly, an essential requirement for islet-derived VEGF in the revascularisation of transplanted mouse islets has recently been reported [45], and another recent study described the rapamycin-mediated inhibition of human islet EC migration and proliferation, and angiogenesis following transplantation of human islets subcutaneously into severe combined immunodeficient (SCID) mice [46]. These data support our findings and highlight the potentially deleterious actions of rapamycin in islet transplantation.

The immunosuppressive regimen of the Edmonton protocol was specifically designed to be steroid-free and calcineurin inhibitor-sparing, with the use of rapamycin and a much reduced dose of tacrolimus [1]. The trough levels of rapamycin targeted in peripheral blood are in the same range as those found to evoke detrimental effects on human islet insulin secretion and to reduce islet VEGF release in our study. In addition, transplanted islets are exposed to higher peak rapamycin levels in the portal blood, which may have concentrations up to twofold higher than those found peripherally [47]. In one study, in which dogs were treated with oral immunosuppressive agents, the portal $C_{\max }$ of rapamycin was found to be $187 \pm 30 \mathrm{ng} / \mathrm{ml}$, compared with a systemic $C_{\max }$ of $91 \pm 13 \mathrm{ng} / \mathrm{ml}$ [48]. Thus, rapamycin exposure could have a major adverse effect on the function and survival of transplanted islets. Additionally, a recent study highlighted a deleterious effect of rapamycin on islet ductal cell proliferation [49]. The authors speculate that this inhibition of ductal neogenesis could be a contributor to the failure of islet grafts in the long term, as has been recently reported [50].

Further refinement of immunosuppressive protocols could increase islet survival, thereby optimising the use of the scarce resource that is the donor pancreas. Our results demonstrate a potential VEGF-mediated autocrine survival pathway that could be exploited to preserve the transplanted islet mass and protect against the detrimental effects of immunosuppressive agents.

Acknowledgements We thank C. Partridge for microscopy, S. Hughes for helpful discussions, D. Wiggins for technical assistance, and the South and South West England and South Wales transplant coordinators for their continued support. This work was supported by unrestricted educational grants from Fujisawa UK, Roche and Wyeth to R. M. Smith, and a grant from the Diabetes Research and Wellness Foundation to P. R. V. Johnson.

Duality of interest The authors declare that there is no duality of interest.

\section{References}

1. Shapiro AMJ, Lakey JR, Ryan EA et al (2000) Islet transplantation in seven patients with type 1 diabetes mellitus using a glucocorticoidfree immunosuppressive regimen. N Engl J Med 343:230-238

2. Ryan EA, Lakey JR, Paty BW et al (2002) Successful islet transplantation: continued insulin reserve provides long-term glycemic control. Diabetes 51:2148-2157

3. Hering BJ, Kandaswamy R, Ansite JD et al (2005) Single-donor, marginal-dose islet transplantation in patients with type 1 diabetes. JAMA 293:830-835

4. Markmann JF, Deng S, Huang X et al (2003) Insulin independence following isolated islet transplantation and single islet infusions. Ann Surg 237:741-749 
5. Bennet W, Groth CG, Larsson R, Nilsson B, Korsgren O (2000) Isolated human islets trigger an instant blood mediated inflammatory reaction: implications for intraportal islet transplantation as a treatment for patients with type 1 diabetes. Upps J Med Sci 105: 125-133

6. Delaney CA, Pavlovic D, Hoorens A, Pipeleers DG, Eizirik DL (1997) Cytokines induce deoxyribonucleic acid strand breaks and apoptosis in human pancreatic islet cells. Endocrinology 138:2610 2614

7. Lakey JR, Suarez-Pinzon WL, Strynadka K et al (2001) Peroxynitrite is a mediator of cytokine-induced destruction of human pancreatic islet beta cells. Lab Invest 81:1683-1692

8. Gerber HP, Dixit V, Ferrara N (1998) Vascular endothelial growth factor induces expression of the antiapoptotic proteins Bcl-2 and A1 in vascular endothelial cells. J Biol Chem 273:13313-13316

9. Gerber HP, McMurtrey A, Kowalski J et al (1998) Vascular endothelial growth factor regulates endothelial cell survival through the phosphatidylinositol 3'-kinase/Akt signal transduction pathway. Requirement for Flk-1/KDR activation. J Biol Chem 273:30336-30343

10. Foster RR, Hole R, Anderson K et al (2003) Functional evidence that vascular endothelial growth factor may act as an autocrine factor on human podocytes. Am J Physiol, Renal Physiol 284:F1263-F1273

11. Villegas G, Lange-Sperandio B, Tufro A (2005) Autocrine and paracrine functions of vascular endothelial growth factor (VEGF) in renal tubular epithelial cells. Kidney Int 67:449-457

12. Gerber HP, Malik AK, Solar GP et al (2002) VEGF regulates haematopoietic stem cell survival by an internal autocrine loop mechanism. Nature 417:954-958

13. Bachelder RE, Crago A, Chung J et al (2001) Vascular endothelial growth factor is an autocrine survival factor for neuropilinexpressing breast carcinoma cells. Cancer Res 61:5736-5740

14. Houck KA, Ferrara N, Winer J, Cachianes G, Li B, Leung DW (1991) The vascular endothelial growth factor family: identification of a fourth molecular species and characterization of alternative splicing of RNA. Mol Endocrinol 5:1806-1814

15. Neufeld G, Cohen T, Gitay-Goren H et al (1996) Similarities and differences between the vascular endothelial growth factor (VEGF) splice variants. Cancer Metastasis Rev 15:153-158

16. Bates DO, Cui TG, Doughty JM et al (2002) VEGF 165 b, an inhibitory splice variant of vascular endothelial growth factor, is down-regulated in renal cell carcinoma. Cancer Res 62:4123-4131

17. Woolard J, Wang WY, Bevan HS et al (2004) VEGF 165 b, an inhibitory vascular endothelial growth factor splice variant: mechanism of action, in vivo effect on angiogenesis and endogenous protein expression. Cancer Res 64:7822-7835

18. Christofori G, Naik P, Hanahan D (1995) Vascular endothelial growth factor and its receptors, flt-1 and flk-1, are expressed in normal pancreatic islets and throughout islet cell tumorigenesis. Mol Endocrinol 9:1760-1770

19. Gorden DL, Mandriota SJ, Montesano R, Orci L, Pepper MS (1997) Vascular endothelial growth factor is increased in devascularized rat islets of Langerhans in vitro. Transplantation 63:436-443

20. Vasir B, Aiello LP, Yoon KH, Quickel RR, Bonner-Weir S, Weir GC (1998) Hypoxia induces vascular endothelial growth factor gene and protein expression in cultured rat islet cells. Diabetes 47:1894-1903

21. Vasir B, Jonas JC, Steil GM et al (2001) Gene expression of VEGF and its receptors Flk-1/KDR and Flt-1 in cultured and transplanted rat islets. Transplantation 71:924-935

22. Watanabe H, Sumi S, Urushihata T et al (2000) Immunohistochemical studies on vascular endothelial growth factor and platelet endothelial cell adhesion molecule-1/CD-31 in islet transplantation. Pancreas 21:165-173

23. Zhang N, Richter A, Suriawinata J et al (2004) Elevated vascular endothelial growth factor production in islets improves islet graft vascularization. Diabetes 53:963-970
24. Sigrist S, Mechine-Neuville A, Mandes K et al (2003) Induction of angiogenesis in omentum with vascular endothelial growth factor: influence on the viability of encapsulated rat pancreatic islets during transplantation. J Vasc Res 40:359-367

25. Johansson U, Olsson A, Gabrielsson S, Nilsson B, Korsgren O (2003) Inflammatory mediators expressed in human islets of Langerhans: implications for islet transplantation. Biochem Biophys Res Commun 308:474-479

26. Kuroda M, Oka T, Oka Y et al (1995) Colocalization of vascular endothelial growth factor (vascular permeability factor) and insulin in pancreatic islet cells. J Clin Endocrinol Metab 80:3196-3200

27. Paty BW, Harmon JS, Marsh CL, Robertson RP (2002) Inhibitory effects of immunosuppressive drugs on insulin secretion from HITT15 cells and Wistar rat islets. Transplantation 73:3531-357

28. Polastri L, Galbiati F, Bertuzzi F et al (2002) Secretory defects induced by immunosuppressive agents on human pancreatic $\beta$-cells. Acta Diabetol 39:229-233

29. Guba M, von Breitenbuch P, Steinbauer M et al (2002) Rapamycin inhibits primary and metastatic tumor growth by antiangiogenesis: involvement of vascular endothelial growth factor. Nat Med 8:128-135

30. Satchell SC, Harper SJ, Tooke JE, Kerjaschki D, Saleem MA, Mathieson PW (2002) Human podocytes express angiopoietin 1, a potential regulator of glomerular vascular endothelial growth factor. J Am Soc Nephrol 13:544-550

31. Richards SK, Parton LE, Leclerc I, Rutter GA, Smith RM (2005) Over-expression of AMP-activated protein kinase impairs pancreatic beta-cell function in vivo. J Endocrinol 187:225-235

32. Gotoh M, Maki T, Kiyoizumi T, Satomi S, Monaco AP (1985) An improved method for isolation of mouse pancreatic islets. Transplantation 40:437-438

33. Wang WY, Whittles CE, Harper SJ, Bates DO (2004) An adenovirus-mediated gene-transfer model of angiogenesis in rat mesentery. Microcirculation 11:361-375

34. Oberg C, Waltenberger J, Claesson-Welsh L, Welsh M (1994) Expression of protein tyrosine kinases in islet cells: possible role of the Flk-1 receptor for beta-cell maturation from duct cells. Growth Factors 10:115-126

35. Lai Y, Schneider D, Kidszun A et al (2005) Vascular endothelial growth factor increases functional beta-cell mass by improvement of angiogenesis of isolated human and murine pancreatic islets. Transplantation 79:1530-1536

36. Hansel DE, Wilentz RE, Yeo CJ, Schulick RD, Montgomery E, Maitra A (2006) Expression of neuropilin-1 in high-grade dysplasia, invasive cancer, and metastases of the human gastrointestinal tract. Am J Surg Pathol 28:347-356

37. Menger MD, Jaeger S, Walter P, Feifel G, Hammersen F, Messmer K (1989) Angiogenesis and hemodynamics of microvasculature of transplanted islets of Langerhans. Diabetes 38(Suppl 1):199-201

38. Stagner J, Mokshagundam S, Wyler K et al (2004) Beta-cell sparing in transplanted islets by vascular endothelial growth factor. Transplant Proc 36:1178-1180

39. Olsson R, Maxhuni A, Carlsson PO (2006) Revascularization of transplanted pancreatic islets following culture with stimulators of angiogenesis. Transplantation 82:340-347

40. Narang AS, Sabek O, Gaber AO, Mahato RI (2006) Coexpression of vascular endothelial growth factor and interleukin1 receptor antagonist improves human islet survival and function. Pharm Res 23:1970-1982

41. Fabian MC, Lakey JR, Rajotte RV, Kneteman NM (1993) The efficacy and toxicity of rapamycin in murine islet transplantation. In vitro and in vivo studies. Transplantation 56:1137-1142

42. Bell E, Cao X, Moibi JA et al (2003) Rapamycin has a deleterious effect on MIN-6 cells and rat and human islets. Diabetes 52:2731-2739

43. Hui H, Khoury N, Zhao X et al (2005) Adenovirus-mediated XIAP gene transfer reverses the negative effects of immunosup- 
pressive drugs on insulin secretion and cell viability of isolated human islets. Diabetes 54:424-433

44. Harada H, Andersen JS, Mann M, Terada N, Korsmeyer SJ (2001) p70S6 kinase signals cell survival as well as growth, inactivating the pro-apoptotic molecule BAD. Proc Natl Acad Sci USA 98:9666-9670

45. Brissova M, Shostak A, Shiota M et al (2006) Pancreatic islet production of vascular endothelial growth factor-A is essential for islet vascularization, revascularization, and function. Diabetes 55:2974-2985

46. Cantaluppi V, Biancone L, Mauriello Romanazzi G et al (2006) Antiangiogenic and immunomodulatory effects of rapamycin on islet endothelium: relevance for islet transplantation. Am J Transplant 6:2601-2611

47. Shapiro AM, Gallant H, Hao E et al (1998) Portal vein immunosuppressant levels and islet graft toxicity. Transplant Proc 30:641

48. Shapiro AM, Gallant HL, Hao EG et al (2005) The portal immunosuppressive storm: relevance to islet transplantation? Ther Drug Monit 27:35-37

49. Bussiere CT, Lakey JR, Shapiro AM, Korbutt GS (2006) The impact of the mTOR inhibitor sirolimus on the proliferation and function of pancreatic islets and ductal cells. Diabetologia 49:2341-2349

50. Ryan EA, Paty BW, Senior PA et al (2005) Five-year follow-up after clinical islet transplantation. Diabetes 54:2060-2069 